\title{
Topraksız ve konvansiyonel koşulların turunçgillerde fidan gelişimi üzerine etkileri
}

\section{The effects of soilless and conventional growing conditions on citrus nursery plant development}

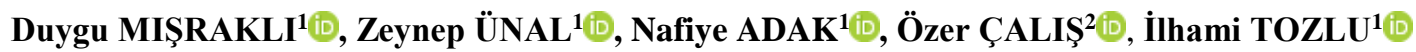 \\ ${ }^{1}$ Akdeniz Üniversitesi, Ziraat Fakültesi, Bahçe Bitkileri Bölümü, 07058, Antalya, Türkiye \\ ${ }^{2}$ Akdeniz Üniversitesi, Ziraat Fakültesi, Bitki Koruma Bölümü, 07058, Antalya, Türkiye \\ Sorumlu yazar (Corresponding author): İ. Tozlu, e-posta (e-mail): itozlu@gmail.com \\ Yazar(lar) e-posta (Authore-mail): misrakli.duygu@gmail.com, unalzeynp7@gmail.com, nafiyeadak@gmail.com,ozercalis@akdeniz.edu.tr
}

\section{MAKALE BİLGİSİ}

Alınış tarihi 12 Mart 2019

Düzeltilme tarihi 19 Nisan 2019

Kabul tarihi 26 Nisan 2019

\section{Anahtar Kelimeler:}

Hava budama

Turunçgil fidan üretimi

Kök morfolojisi

Topraksız fidan üretimi

Endomikoriza

\begin{abstract}
ÖZ
Turunç anacı üzerine aşılanmış Meyer limonlarında farklı Mikoriza ve Mikrobiyal Gübre türlerinin fidan büyümesine olan etkileri incelenmiștir. Toprak kökenli hastalık ve zararlılardan ari turunçgil fidanı üretmek için fidanlarda hava budaması uygulaması yapılmışıır. Hava budaması uygulaması yapılmış fidanlarda özel olarak formüle edilmiş topraksız bitki besleme uygulamaları yapılarak, güçlü, kök kıvrılması olmayan ve kökü toprağa geçmiş fidanlarla rekabet edebilecek fidan üretiminin yapılması amaçlanmıștır. Araştırma Nisan-Kasım 2017 tarihleri arasında Akdeniz Üniversitesi Ziraat Fakültesinde ışık miktarıın 303.00 ile 1988.85 lüks arasında ölçüldüğü seralarda yürütülmüsştür. Deneme 3 tekerrürlü ve her tekerrürde 5 fidan olacak şekilde kurulmuștur. Denemede fidanlar 3:1 oranında torf ve pomza ortamı içeren tüplere şaşırtılmıștır. Araştırmada dönemlere göre değișmekle

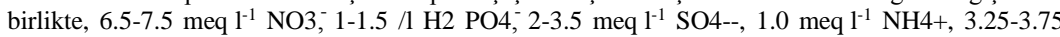
meq ${ }^{1-1} \mathrm{~K}+, 3-5.5$ meq $^{1-1} \mathrm{Ca}++, 1.25-2.0$ meq $\mathrm{l}^{-1} \mathrm{Mg}++$ toprakssz bitki besleme formülasyonu olarak kullanılmıstır. Mikoriza karıșımı olarak Glomus spp.: G. mosseae, G. etunicatium, G. clarium, G. intraradices, G. caledonium, G. macrocarpium, G. margarita, G. fasciculatum türlerinin 500 spor/bitki dozlarına karşılık gelecek şekilde bitki başına $50 \mathrm{~g}$ mikoriza karışımı harç uygulanmıştır. Mikrobiyal gübre olarak Yeditepe Üniversitesi, Genetik ve Biyomühendislik Bölümünden temin edilen "köklendirici + baktobost np + baktogrop" olmak üzere üç faklı formülasyonu karıştırılarak $\left(150 \mathrm{cc} \mathrm{bitki}^{-1}\right)$ köklere muamele edilmiştir. Ayrıca mikoriza uygulanmış bitkilere bakteriyel gübre uygulaması da yapılarak her iki karışımın birlikte uygulandığındaki etkileri de arașıııılmıștır. Araștırmada; sürgün boyu, anaç-kalem çapı, yaprak alanı, kök bölgesinde mikoriza sayımı (adet), mikorizal kök enfeksiyon oranı (\%), topraktaki toplam bakteri sayısı ile kök enfeksiyonlarının belirlenmesi çalıșlacak parametreler olarak planlanmıștır. Sonuçlar mikoriza ve mikrobiyal gübre uygulamalarının anaç ve kalem çapı ile bitki büyümesi üzerine etkili olmadığını ancak klorofil ve yaprak alan indeksleri üzerine etkili olduğunu göstermiş̧tir.
\end{abstract}

\section{ARTICLE INFO}

Received 12 March 2019

Received in revised form 19 April 2019

Accepted 26 April 2019

\section{Keywords:}

Air pruning

Root Morphology

Soilless Citrus Nursery plant production

Endomikoriza AMF

\begin{abstract}
The effects of different Mycorrhiza species and microbial fertilizers to nursery plant performances of Meyer lemon plants grafted on sour orange rootstock were investigated. Air pruning technique was applied to roots to produce soil born pests free nursery plants. Ferti-irrigation with specially formulated soilless nutrient solution was applied to air pruning suitable pots to produce plants that are free from root circling, vigorous and can compete with well-developed conventional nursery plants that have soil penetrated roots. The study was conducted in a greenhouse that belongs to Akdeniz University Agricultural Faculty and that had light intensity between 303.00-1988.85 lx during April to November of 2017. The research was conducted with three replications each of which had five plants. Growing media was the 3:1 mixture of peat moss and pumice. Experimented Mycorrhiza mixture was consist of Glomus spp.: G. mosseae, G. etunicatium, G. clarium, $G$. intraradices, G. caledonium, G. macrocarpium, G. margarita, G. fasciculatum species. The dose of mycorrhiza mixture was 500 spores/plant $(50 \mathrm{~g}$ of mycorrhiza). As a microbial fertilizer, provided by Department of Genetics and Bioengineering, Yeditepe University, three different formula "root promoter + baktobost np + baktogrop" were applied to experimented plants. Measurements included; rootstock and scion diameters, shoot length, chlorophyll and leaf area indexes, root mycorrhizal and bacterial infection ratio (\%) and number of spores and bacteria in rhizosphere. The results showed that while mycorrhiza and microbial fertilizers had no effect on rootstock and scion diameters and shoot length, mycorrhizae had influence on chlorophyll and leaf area indexes.
\end{abstract}




\section{Giriş}

Turunçgiller $40^{\circ}$ Kuzey ve $40^{\circ}$ Güney paraleller arasındaki bölgelerde üretimi yapılan ve dünyada en fazla ticari hacme sahip meyve grubudur (Davies ve Albrigo 1994). Dünya üzerinde yaklaşık 9.5 milyon hektar (ha) alanda 146.4 milyon ton turunçgil üretimi yapılmaktadır. En büyük turunçgil üreticisi ülkeler; sırasıyla, Çin (32.7 milyon ton), Brezilya (16.6 milyon ton) ve Hindistan (9.8 milyon ton) dir (FAO 2017). Ülkemiz ise 2013 yılinda 3.7 milyon ton, 2014-2015 sezonunda 3.8 milyon ton ve 2016 yılında 4.3 milyon ton üretim ile önemli turunçgil üreticisi ülkeler arasında 8. sırada yer almaktadır (FAO 2018). Yaş meyve-sebze ihracatımızın \%40'ını oluşturan turunçgiller, ihracat hacmi bakımından ülkemiz içinde en önemli meyve grubunu oluşturmaktadır (Anonim 2016). Akdeniz ihracatçı birliklerinin 2016 yılı verilerine göre mandarin ve portakaldan miktar olarak \%30, değer olarak ise \%120'den daha fazla ihracatı gerçekleştirilen limon, turunçgil grubu içerisinde gerek miktar gerekse döviz hacmi olarak en fazla ihracatı yapılan türdür. Türkiye limon üretimi bakımından dünyada 8 . sırada, ihracat bakımından ise İspanya ve Meksika'dan sonra 3. sırada yer almaktadır (FAO 2017).

Tarımsal üretimin tüm kollarında olduğu gibi, üretime sağlıklı materyalle başlanması turunçgil sektörünün sürdürülebilirliğinde de hayati öneme sahiptir. Turunçgillerde sağlıklı fidan; ismine doğru, güçlü bir gelişme gösteren, anaç kalem kombinasyonlarında sorunu olmayan, hastalık ve zararlılardan ari fidanlar olarak değerlendirilmektedir. Fidanların üretim sırasında toprakla temasının kesilmesi hastalıktan ari materyal üretimi için son derece önemlidir. Üretim sirasında toprakla temasın tamamen kesildiği durumlarda ise tüpün tabanına ulaşan kökler kıvrılmakta, fidanlar daha zayıf gelişmekte, cılız kalmakta ve bu da fidan alıcısı tarafindan talep görmemesine neden olmaktadır (Kahlke ve ark. 2005). Bunu önlemek için geliştirilen köklerde hava budama, taban kısmı olmayan saksılar içerisindeki fidanların toprakla irtibatı kesilerek yerden yükseltilmiş tezgâhlar üzerinde üretim esasına dayanan bir tekniktir. Genellikle kökleri kılavuzlarla aşağıya doğru yönlendirilmiş saksıların kullanıldı̆̆ bu sistemde saksının tabanına ulaşan kökler havayla temas ettiğinde büyümesini durdurmakta ve saçak kök oluşturmasını teşvik etmektedir (Schumann ve ark. 2015 ).

$\mathrm{Bu}$ nedenlerle planlanan bu araştırmada, toprak kökenli hastalık ve zararlılardan ari gelişimi iyi turunçgil fidanı üretmek için fidanlarda özel bitki besleme uygulamaları ve hava budaması uygulaması yapılarak, güçlü, kök kıvrılması olmayan ve kökü toprağa geçmiş fidanlarla rekabet edebilecek fidan üretiminin yapılması amaçlanmıştır (Mışraklı 2018). Bu kapsamda, topraksız bitki besleme uygulaması ile mikoriza ve mikrobiyal gübrelerin tek tek veya kombine edilmiş olarak uygulamalarının, standart fidan yetiştiriciliğine göre, fidan kalitesi üzerine etkileri Turunç anacı üzerine aşılı Meyer limonlarında morfolojik ve fizyolojik olarak incelenmiştir.

\section{Materyal ve Yöntem}

Denemede bitkisel materyal olarak turunç anacı kullanılmış olup, bu anaçlar Antalya'da bulunan Mazlum Fidancılık tarafından üretilmiştir. Çöğür üretim seralarında Ocak (2016) ayında turunç tohumlarının ekimi yapılmış ve nüseller çöğürler Temmuz ayında torf ve pomza ortamı (3:1) içeren tüplere şaşırtılmıştır. Mart-Nisan (2017) aylarında nüseller çöğürler 20 cm'den aşılanmış ve gözler patlamadan (sürgün vermeden) araştırmanın yürütüldüğü Akdeniz Üniversitesi Ziraat Fakültesi Bahçe Bitkileri Bölümü seralarına getirilmiş ve aşağıda açıklanan iki farklı ortama alınmıştır.

Araştırmada 6 (altı) farklı uygulama yapılmıştır. İki uygulamada çiftçi koşullarını test etmek için Doğu Akdeniz bölgesindeki Turunçgil fidan üreticilerinin çoğunluğunun kullandığ 1 standart $27 \times 27 \mathrm{~cm}$ üst ve $27 \times 27 \mathrm{~cm}$ taban ölçülerine sahip ve $32 \mathrm{~cm}$ derinliğindeki 8 l'lik körüksüz plastik fidan üretim torbaları kullanılmıştır (Şekil 1). Bu uygulamalarda çiftçi koşullarında kullanılan 3:1:1 oranında Toprak: Kum: çiftlik gübresi karışımından hazırlanmış ortam kullanılmıştır. Kontrol uygulaması olan birinci uygulamada (Uyg-1; T-ÇK), fidanlar serada oluşturulan toprak zemin üzerine bırakılmış ve çiftçi koşullarına uygun besleme koşulları sağlanarak köklerinin toprağa atmasına izin verilmiştir (Şekil 1). Beslemede Türkiye Turunçgil fidan üretiminin \%30'unu gerçekleştiren üç büyük fidan işletmesinin (Z.E.Y.N.A.R. Fidancılık, Serkan Fidancılık ve Naim Fidancılık) besleme uygulamaları referans alınmıştır.
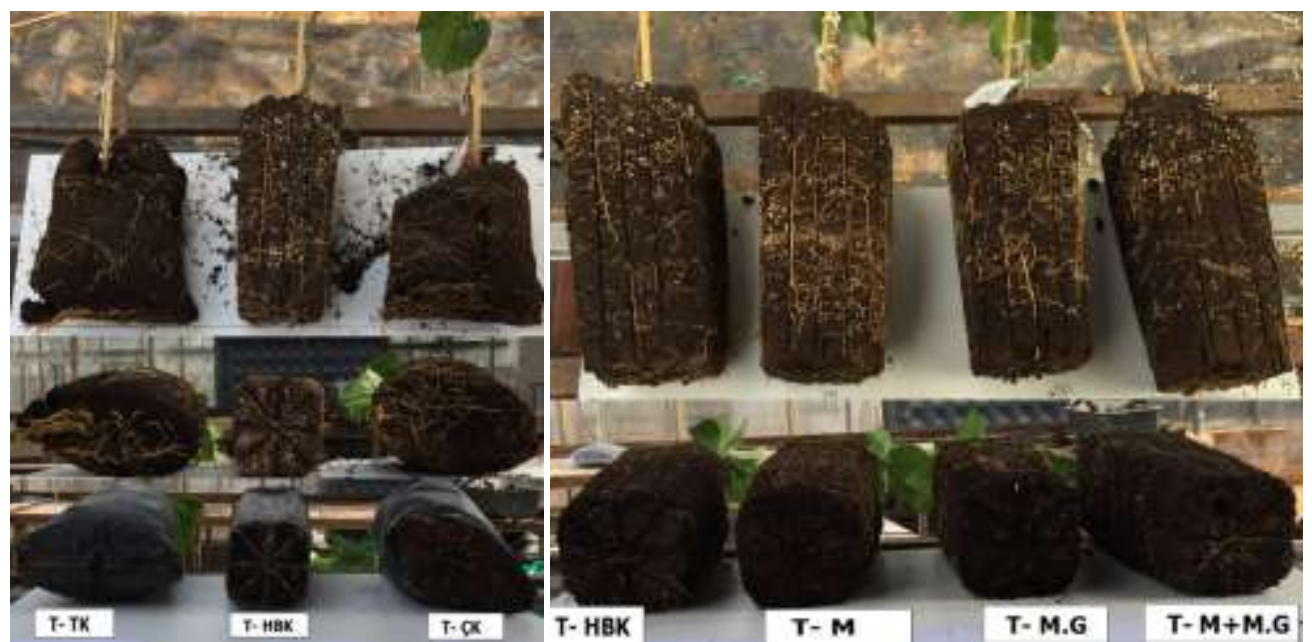

Şekil 1. Fidan torbası ve hava budama saksılarında farklı ortam ve besleme uygulaması yapılan kontrol (sol) ve mikroorganizma uygulanmış hava budama saksılarındaki bitkilerin (sağ) kök gelişimleri.

Figure 1. Root development of the plants grown in nursery bags and air pruning pots with different media and nutrient applications; control (left), air pruning pots in which microorganisms are applied (right). 
Buna göre fidan başına $15 \mathrm{~g}$ gelecek şekilde 20:20:0 taban gübresi ilave edilmiştir. Daha sonra aylık uygulamalar şeklinde toplam 25 g 15:15:15 ve 25 g 4x15 (15:15:15:15; N:P:K+SO3) verilmiştir. Saf madde olarak fidan başına $11 \mathrm{~g} \mathrm{~N}, 11 \mathrm{~g} \mathrm{P}, 7,5 \mathrm{~g}$ $\mathrm{K}$ ve 3,75 g SO3 uygulanması yapılmıştır. Diğer tüplü uygulama olan Uyg-2, T-TK'da fidanlar diğer dört uygulama gibi tezgâhlar üzerine alınarak zeminle ilişkisi kesilmiş ve topraksı üretim formülasyonu ile beslenerek bu bitkilerin toprağa kök atmadan güçlü bir şekilde gelişip gelişmeyeceği test edilmiştir (Şekil 1). Formülasyon olarak Furlani ve ark. (2009)'nin besin formülasyonunun yetiştirme ortamı ve iklim şartlarımıza uyarlanmış hali kullanılmıştır. Nisan-Ekim ayları arasında yapılacak uygulamaya göre üç farklı dönem belirlenmiş ve her dönemde sulama suyunun $\mathrm{K}, \mathrm{Na}, \mathrm{Ca}, \mathrm{Mg}$, $\mathrm{Cl}, \mathrm{pH}, \mathrm{EC}, \mathrm{SAR}, \mathrm{RSC}, \mathrm{SO} 4, \mathrm{HCO} 3$ ve $\mathrm{CO} 3$ değerleri ile transpirasyona göre farklı EC değeri uygulanmıştır (çizelge 1).

Saksıda yapılan diğer dört uygulamada ise boyutları 16x16 $\mathrm{cm}$ üst ve $12 \times 12 \mathrm{~cm}$ taban ölçülerinde ve $35 \mathrm{~cm}$ derinliğindeki hava budamaya uygun kare siyah saksılar kullanılmıştır. Bu saksılar Uyg-2, T-TK uygulaması ile birlikte gelişmiş ülkelerde hastalıktan ari fidan üretiminde ve karantina koşullarında yaygın olarak kullanılan tezgâhlar üzerinde tutulmuştur. Topraksız üretim besleme formülasyonu kullanılan bu uygulamalar hava budamalı kontrol (Uyg-3 ;T-HBK), yanında Yeditepe Üniversitesi Mühendislik ve Mimarlık Fakültesi Genetik ve Biyomühendislik Bölümünden temin edilen; Bacillus subtilis, Bacillus megaterium ve Lactococus spp. bakterilerinin her biri $30 \mathrm{cc}$ mikroorganizma/1.5 1 su oranında karışımından oluşan mikrobiyal gübre uygulaması (Uyg-4; TMG), Çukurova Üniversitesi Ziraat Fakültesi Toprak Bölümü'nden temin edilen ve bitki başına $50 \mathrm{~g}$ Glomus spp. G. mosseae, G. etunicatium, G. clarium, G. intraradices, G. caledonium, G. macrocarpium, G. margarita, G. fasciculatum mikoriza mantarlarının karışım kokteyli uygulaması (Uyg-5; TM) ve son olarak ta Mikoriza ve Mikrobiyal Gübre karışımı uygulaması (Uyg-6; T-M+MG) kullanılmıştır. Sonuç olarak yapılan altı farklı uygulamada iki farklı konteyner (plastik torba ve saks1) ve ortamlardaki bitkilere iki faklı besleme uygulamas1 yapılmıştır. Bitki besleme dışındaki bakım işlemleri (sulama, ilaçlama, sürgün alma vb.) tüm uygulamalarda aynı şekilde homojen olarak gerçekleştirilmiştir (Şekil 1).

Sicaklık ölçümleri HOBO U12-012 datalogger Temperature/ Relative Humidity (temp/RH) datalogger cihazı tarafından saatlik olarak kayıt altına alınmıştır. Işık, Testo 540 Işık Şiddeti (lux) ölçüm cihazı ile ölçülmüştür. Anaç ve sürgün çapları aşı noktasının $5 \mathrm{~cm}$ altından (anaç) veya üstünden (sürgün) mm dijital kumpas ile yapılmıştır. Sürgün boyu, gözlerin sürmeye başlaması ile birlikte aşı noktasından itibaren mezür ile $\mathrm{cm}$ cinsinden ölçülmüştür. Ölçümler 20 gün aralıklarla toplam dokuz kez yapılmıştır. Deneme sonunda bitkinin toprak üstü ve kök yaş ve kuru ağırlıkları belirlenmiştir.

Klorofil indeksi Spectrum Technologies FieldScout CM1000 Model Klorofil Metre kullanılarak her bitkinin en alt, orta ve en üstteki yapraklarının ölçümü ile, yaprak alanı indeks değeri rastgele seçilen bir yaprakta Accupar-LP80 cihazı ile, yaprağın sıcaklığı infrared termometre (TESTO 810) yardımı ile belirlenmiştir. Tüm ölçümler 20 günde bir gün 1şığının yoğun olduğu 10.00-12.00 saatleri arasında yapılmıştır.

Mikorizal kök enfeksiyon oranı (\%) Phillips ve Hayman (1970) ve Y1lmaz (2005)'a göre, Rizosferde Bulunan Mikoriza sayımları ise Çağlar ve ark. (2004)'na göre yapılmıştır. Topraktaki toplam bakteri sayısı Saygılı ve ark. (2006)'na göre yapılmıştır.

Verilerin Değerlendirilmesi: Çalışma sonucunda elde edilen veriler Tesadüf Parselleri Deneme Desenine uygun olarak varyans analizi ile değerlendirilerek, SPSS 17.0 istatistik paket programında Tek Yönlü ANOVA kullanılarak farklılık durumları incelenmiştir. Ortalamalar arasında önemli farklılıklar $(\mathrm{P}<.05)$ önem düzeyinde belirlenmiştir.

\section{Bulgular}

Büyüme parametreleri uygulamalar arasında farklılıklar göstermiştir. Anaç çapı ölçümlerinde topraksız fertigasyon uygulanan tüplü bitkiler (T-TK) en başarılı sonucu verirken

Çizelge 1. Farklı dönemlerde uygulanan sürekli besleme formülasyonları.

Table 1. Continuous feeding formulations applied at different stages.

\begin{tabular}{|c|c|c|c|}
\hline Makro Elementler & Konsantrasyonlar $\left(\right.$ meq l$\left.^{-1}\right)$ & Mikro Elementler & Konsantrasyonlar $\left(\mu \mathrm{mol} \mathrm{l}{ }^{-1}\right)$ \\
\hline \multicolumn{4}{|c|}{ 1. Dönem (Nisan-Mayıs) } \\
\hline $\mathrm{NO}_{3}^{-}$ & 7 & $\mathbf{F e}$ & 15 \\
\hline $\mathrm{H}_{2} \mathrm{PO}_{4}$ & 1.25 & $\mathrm{Mn}$ & 6 \\
\hline $\mathrm{SO}_{4}^{--}$ & 3.50 & $\mathrm{Zn}$ & 5 \\
\hline $\mathbf{N H}_{4}^{+}$ & 1.0 & B & 15 \\
\hline $\mathbf{K}^{+}$ & 3.5 & $\mathbf{C u}$ & 0.75 \\
\hline $\mathrm{Ca}^{++}$ & 5.5 & Mo & 0.50 \\
\hline $\mathbf{M g}^{++}$ & 2.0 & & \\
\hline \multicolumn{4}{|c|}{ 2. Dönem (Haziran-Ağustos) } \\
\hline $\mathrm{NO}_{3}^{-}$ & 6.5 & $\mathbf{F e}$ & 15 \\
\hline $\mathrm{H}_{2} \mathrm{PO}_{4}$ & 1.00 & $\mathrm{Mn}$ & 6 \\
\hline $\mathrm{SO}_{4}^{--}$ & 3.00 & $\mathrm{Zn}$ & 5 \\
\hline $\mathrm{NH}_{4}^{+}$ & 1.0 & B & 15 \\
\hline $\mathbf{K}^{+}$ & 3.25 & $\mathrm{Cu}$ & 0.75 \\
\hline $\mathrm{Ca}^{++}$ & 5.0 & Mo & 0.50 \\
\hline $\mathbf{M g}^{++}$ & 1.50 & & \\
\hline \multicolumn{4}{|c|}{ 3. Dönem (Eylül-Ekim) } \\
\hline $\mathrm{NO}_{3}^{-}$ & 7.5 & $\mathbf{F e}$ & 15 \\
\hline $\mathrm{H}_{2} \mathrm{PO}_{4}$ & 1.50 & $\mathrm{Mn}$ & 6 \\
\hline $\mathrm{SO}_{4}^{--}$ & 2.00 & $\mathrm{Zn}$ & 5 \\
\hline $\mathbf{N H}_{4}{ }^{+}$ & 1.0 & B & 15 \\
\hline $\mathbf{K}^{+}$ & 3.75 & $\mathrm{Cu}$ & 0.75 \\
\hline $\mathrm{Ca}^{++}$ & 3.0 & Mo & 0.50 \\
\hline $\mathrm{Mg}^{++}$ & 1.25 & & \\
\hline
\end{tabular}


sürgün uzunluğu bakımından ise en düşük değerleri vermiştir (Çizelge 2). Sürgün çapı bakımında mikroorganizma uygulamaları (T-M ve T-MG) diğer uygulamalardan daha düşük değer verirken, sürgün uzunluğu bakımından mikroorganizma karışımı uygulaması ( $\mathrm{T}-\mathrm{M}+\mathrm{MG})$ en yüksek değeri vermiştir.

Deneme sürecinde bitki büyüme ve gelişme ölçümleri yanında bazı fotosentetik yaprak parametrelerinin ölçümleri de yapılmıştır. Ölçümü yapılan bu parametreler, klorofil ve yaprak alan indeksleri ile yaprak sicaklığı olup bulunan değerler Çizelge 3'de görülmektedir. Bitki büyüme parametreleri (anaç çap1, sürgün çap1 ve sürgün boyu) üzerine etkisi saptanamayan mikoriza uygulaması, T-MG uygulaması ile birlikte yapraktaki klorofil miktarına ve yaprak alan indeks değerlerine etki etmiştir (Çizelge 3). Genel olarak hava budama uygulamalarının göreceli olarak Tüplü uygulamalara göre klorofil miktarını artırdığı saptanmıştır. Yaprak alan indeksi T-ÇK uygulamasında diğer tüm uygulamalara göre değer ve standart hata olarak olağanüstü yüksek bulunmuştur. En düşük değer ile en yüksek değerler sirasiyla 74 ve 234 (veri gösterilmemektedir) arasındadır. $\mathrm{Bu}$ sonucun aslında taç gölgelemesinin bir göstergesi olan yaprak alan indeksi araştırmanın doğası gereği T-ÇK uygulamasının yüzey alanı daha geniş olan fidan torbalarının kullanımı ile yerde ve diğer uygulamalardan ayrı kurulmasından kaynaklandığı düşünülmektedir.

\subsection{Kök ve Rizosferde Mikroorganizma Belirlenmesi}

Bitki köklerinde mikoriza aşılamasından dolayı yüksek oranda kök enfeksiyonu (\%82) belirlenmiştir (Şekil 2; Çizelge 4). Bu sonuç Hetrick ve Wilson (1989) raporu ile örtüşmektedir.
Araştırmacılar steril edilmemiş ve düşük verimlilik koşullarında turunç bitkisinin büyümesinin ve mikorizal kök enfeksiyonun azaldığını bildirmişlerdir. Turunçgiller, mikoriza olmaksızın optimum gelişme sağlamakta güçlük çekmektedir (Menge ve ark. 1978; Ortaş ve ark. 2002a,b). Benzer şekilde Nunes ve ark. (2006) yaptıkları çalışmada turunçgil bahçelerinden iki farklı mevsimde kök ve toprak örnekleri almışlar ve mikorizal kolonizasyonu her iki dönemde de yüksek oranda bulmuşlar ve kök enfeksiyonunun \%42 ile \%83 arasında değiştiğini tespit etmişlerdir.

Rizosferden alınan örnekte yapılan mikoriza sayımında spor sayısı T-M uygulamasında 80 T-M+MG uygulamasında 64 olarak bulunmuştur. Bu sonuç T-MG uygulamasında olası bir antagonistik etkiyi işaret etmekte olup mikoriza'nın yalnız uygulanmasının daha etkili olduğunu göstermiştir. (Çizelge 4).

En yüksek bakteri sayısı Kontrol $\left(10 \times 10^{9}\right)$ uygulamalarında saptanmış, bunu Mikoriza ve Mikrobiyal Gübre uygulamaları takip etmiştir (Çizelge 5). Mikoriza ve Mikrobiyal Gübre uygulamalarında kontrollere göre daha düşük sayıda bakteri saptanmasının sebebinin Mikoriza ve Mikrobiyal Gübre içerisindeki mikroorganizmaların zararlı mikroorganizmaları kontrol altına almaları nedeniyle mikroorganizma aktivitelerinin yararlı olanlarla sınırlanmasından olabileceği bildirilmiştir (Mışraklı 2018). Bitki Gelişimini Uyaran Kök bakterileri (Plant Growth Promoting Rhizobacteria -PGPR-) genellikle kök sisteminde kolonize olarak bitki gelişimini düzenlemekte ve zararlı rizosfer mikroorganizmalarını bask1 altında tutmaktadırlar (Sıddıqui 2006; Güneş ve ark. 2009). Topraktaki en yüksek bakteri sayısı kontrol bitkilerinde saptanmıştır.

Çizelge 2. Uygulamaların bitki büyüme parametreleri üzerine etkisi.

Table 2. Effect of applications on plant growth parameters.

\begin{tabular}{lccc}
\hline Uygulama & Anaç Capı (mm) & Sürgün Çapı (mm) & Sürgün Boyu (cm) \\
\hline HBK & $6.90 \pm 0.20 \mathrm{ab}$ & $4.64 \pm 0.16 \mathrm{a}$ & $38.47 \pm 2.81 \mathrm{ab}$ \\
MG & $6.93 \pm 0.73 \mathrm{ab}$ & $3.61 \pm 0.14 \mathrm{~b}$ & $36.13 \pm 3.00 \mathrm{ab}$ \\
M & $6.63 \pm 0.17 \mathrm{~b}$ & $3.35 \pm 0.09 \mathrm{~b}$ & $34.67 \pm 3.59 \mathrm{ab}$ \\
MG+ M & $6.97 \pm 0.16 \mathrm{ab}$ & $4.97 \pm 0.13 \mathrm{a}$ & $45.87 \pm 2.78 \mathrm{a}$ \\
ÇK & $7.17 \pm 0.59 \mathrm{ab}$ & $4.87 \pm 0.13 \mathrm{a}$ & $40.13 \pm 2.44 \mathrm{ab}$ \\
TK & $7.52 \pm 0.69 \mathrm{a}$ & $4.99 \pm 0.11 \mathrm{a}$ & $32.33 \pm 2.36 \mathrm{~b}$ \\
\hline
\end{tabular}

Çizelge 3. Uygulamaların yaprak klorofil indeksi, yaprak alan indeksi ve yaprak sıcaklığı üzerine etkileri.

Table 3. The effects of applications on leaf chlorophyll index, leaf area index and leaf temperature.

\begin{tabular}{llcc}
\hline Uygulama & Klorofil İndeksi & Yaprak Alan İndeksi & Yaprak Sicaklı̆̆ $\left({ }^{\circ} \mathbf{C}\right)$ \\
\hline HBK & $130.60 \pm 10.98 \mathrm{ab}$ & $37.33 \pm 2.63 \mathrm{~b}$ & $22.22 \pm 0.41 \mathrm{ab}$ \\
MG & $172.47 \pm 14.396 \mathrm{a}$ & $41.13 \pm 2.44 \mathrm{~b}$ & $21.86 \pm 0.40 \mathrm{ab}$ \\
M & $146.06 \pm 17.63 \mathrm{a}$ & $28.13 \pm 2.63 \mathrm{~b}$ & $21.46 \pm 0.40 \mathrm{ab}$ \\
MG+ M & $130.73 \pm 19.85 \mathrm{ab}$ & $38.80 \pm 4.83 \mathrm{~b}$ & $21.68 \pm 0.26 \mathrm{ab}$ \\
ÇK & $36.20 \pm 1.75 \mathrm{c}$ & $193.46 \pm 39.55 \mathrm{a}$ & $21.26 \pm 0.29 \mathrm{~b}$ \\
TK & $74.47 \pm 9.06 \mathrm{bc}$ & $30.00 \pm 19.00 \mathrm{~b}$ & $23.24 \pm 0.82 \mathrm{a}$ \\
\hline
\end{tabular}

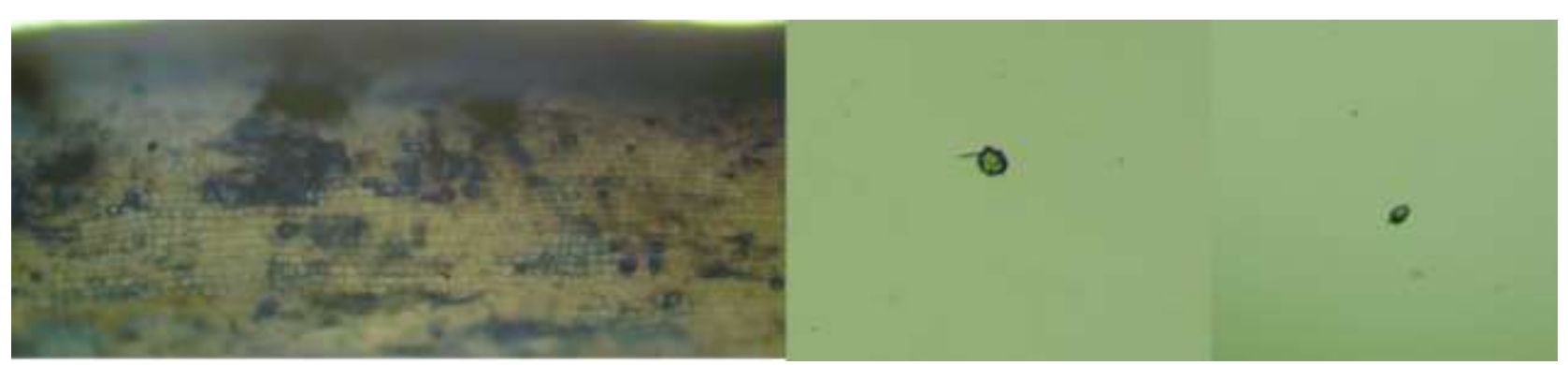

Şekil 2. Kök bünyesinde ve rizosfer bölgesinde bulunan mikoriza.

Figure 2. Mycorrhizae found in the root and rhizosphere. 
Çünkü buralarda mikrobiyal etkiyi veya mikroflorayı değiştirecek bir uygulama yoktur. Ancak T-M uygulamasında belirlenen bakteri miktarının, T-MG'ye göre daha az olduğu görülmekte olup bunun da mikoriza ve mikrobiyal gübredeki bakterilerin üretmiş olduğu ve kök bölgesinde salgıladığ antimikrobiyal kimyasallardan dolayı olduğu düşünülmektedir. Mikorizal kolonizasyonun, bitkilere bitki beain elementleri sağlamaları yanında (Cavagnaro ve ark. 2006; Singh ve ark. 2001), toprak kökenli zararlılara karşı dayanıklılı̆̆ 1 da artırdığ 1 gösterilmiştir (Pozo ve Azcon-Aguilar 2007).

Çakmakçı (2005)'nın da belirttiği gibi, biyolojik gübrelemede kullanılan bakteri ırklarının etkinliği, inokulumun kalitesi, bitki çeşidi, kültür koşulları, toprak özellikleri, sıcaklık, nem rejimi, toprak yapısı, aşılama-uygulama tekniği ve gübreleme düzeyine bağlı olarak değişmektedir. Bu faktörlerin biri veya birkaçı uyumsuzluk gösterdiğinde biyolojik preparatın etkisiz kalması ve yerel 1rklarla rekabet gücünün azalması olasıdır. Çalışmamızda da bahsi geçen bu faktörlerin bazılarının uyumsuz olabileceği ve kullanılan bakteri ırklarının toprak çevresindeki bakterilerle rekabet ederek kolonize olduğu, diğer bakterilerin bu ortamda gelişemediği düşünülmektedir. $\mathrm{Bu}$ faydalı bakterilerin sayısındaki artış bitki gelişimine yansımış olup, Mikrobiyal Gübre içeren uygulamalarda bakteri rrklarının kontrolden daha az bakteri değerleri verdiği ortaya çıkmıştır.

\section{Tartışma ve Sonuç}

Fidanların büyümesi ve bitki gelişimi yönünden mikorizanın anaç çap1, sürgün çap1 ve sürgün boyuna etki etmediği ancak yapraktaki klorofil miktarına ve yaprak alan indeks değerlerine etki ettiği tespit edilmiştir. Bitki köklerinde mikoriza aşılamasından dolayı yüksek oranda kök kolonizasyonu (\%82) belirlenmiştir. Uygulanan mikoriza ve PGPR'lerin rizosferdeki kolonileşme miktarları bireysel uygulamalarda kombine uygulamalara göre daha fazla bulunmuştur. Bireysel veya kombine olarak uygulanan mikroorganizmalar (Mikoriza ve PGPR) rizosferdeki diğer mikroorganizma faaliyetleri sınırlandırmıştır.

\section{Teşekkür}

$\mathrm{Bu}$ araştırma Akdeniz Üniversitesi Bilimsel Araştırma Projeleri Koordinasyon Birimince desteklenmiştir. Yazarlar ayrıca araştırmaya mikoriza karışımı sağlayan Ç.Ü. Ziraat Fakültesi Toprak Bilimi ve Bitki Besleme Bölümü öğretim üyesi Prof. Dr. İbrahim ORTAŞ’a ve Mikrobiyal gübre sağlayan Yeditepe Üniversitesi Genetik ve Biyomühendisliği Bölümü öğretim üyesi Prof. Dr. Fikrettin ŞAHIN'e, bitkisel materyali sağlayan Mazlum Fidancılığa teşekkür eder.

Çizelge 4. Kök bünyesinde ve kök bölgesindeki (rizosfer) mikoriza sayımı.

Table 4. Mycorrhizal count in the root and root region (rhizosphere).

\begin{tabular}{lcc}
\hline & Kök Bölgesi spor sayısı/10 g harç ortamı (adet) & Kök Bünyesi Enfeksiyon oranı (\%) \\
\hline HBK & 0 & 0 \\
MG & 0 & 0 \\
M & 130 & 80 \\
MG+ M & 90 & 64 \\
ÇK & 0 & 0 \\
TK & 0 & 0 \\
\hline
\end{tabular}

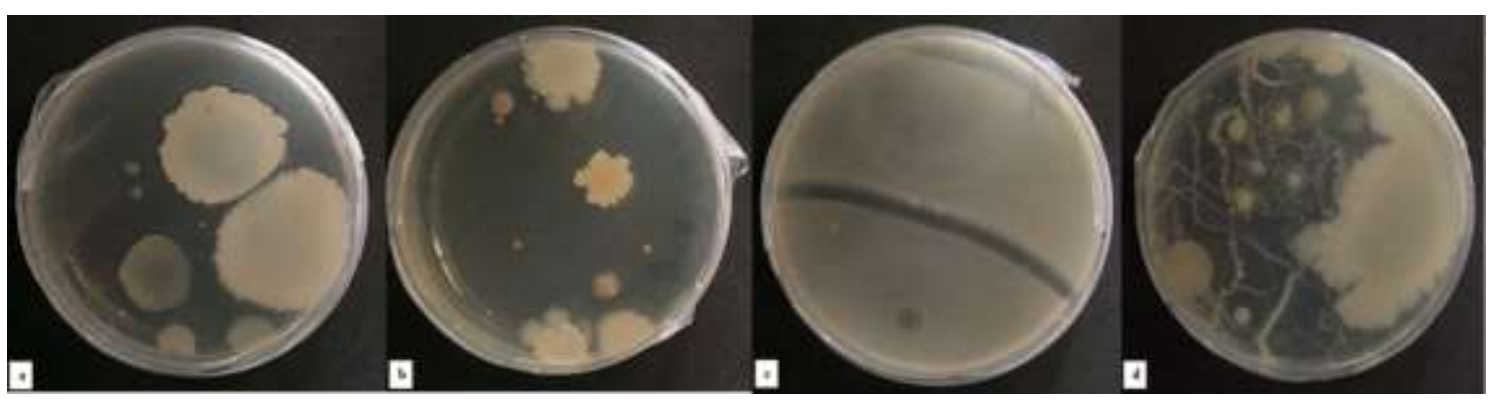

Şekil 3. Uygulama ortamlarında yapılan bakteri kültürü sonucunda oluşan koloniler; a- M, b-MG, c-M+MG ve d-HBK.

Figure 3. The colonies formed as a result of bacterial culture prepared for different applications; $a-M, b-M G, c-M+M G$ and d-HBK.

Çizelge 5. Rizosferde bulunan ve "Colony Forming Unit" (CFU/1 g) belirlenen toplam bakteri olarak miktarı

Table 5. The total amount of bacteria in the rhizosphere determined as Colony Forming Unit (CFU / $1 \mathrm{~g}$ ).

\begin{tabular}{lc}
\hline Uygulamalar & Toplam Bakteri Miktarı (CFU/1 g) \\
\hline HBK & $10 \times 10^{9}$ \\
MG & $7 \times 10^{9}$ \\
M & $8 \times 10^{9}$ \\
MG+ M & $19 \times 10^{9}$ \\
ÇK & $10 \times 10^{9}$ \\
TK & $10 \times 10^{9}$ \\
\hline
\end{tabular}




\section{Kaynaklar}

Anonim (2016) Yaş meyve sebze ihracatçıları birliği değerlendirme raporu. 2014-2015 Ocak-Aralık. [http://www.akib.org.tr/files/downloads/arastirmaraporlari/ysm/yms -degerlendirme-raporu-Ocak-Aralik-2015.pdf].

Cavagnaro TR, Jackson EL, Six J, Ferris H, Goyal S, Asami D, Scow KM (2006) Arbuscular mycorrhizas, microbial communities, nutrient availability, and soil aggregates in organic tomato production. Plant and Soil 282: 209-225.

Çağlar S, Sütyemez M, Bayazit S (2004) Seçilmiş Bazı Ceviz (Juglans regia) Tiplerinin Stoma Yoğunlukları. Akdeniz Üniversitesi Ziraat Fakültesi Dergisi 17(2): 169-174.

Çakmakçı R (2005) Bitki gelişimini teşvik eden rizobakterilerin tarımda kullanımı. Atatürk Üniversitesi Ziraat Fakültesi Dergisi 36(1): 97 1007.

Davies FS, Albrigo LG (1994) Rootstocks. In: Athern J. Rees. A. (Eds.), Citrus, CAB International, Wallingford, UK, pp. 254.

FAO (2017) Statistical Yearbook of the Food And Agricultural Organization for the United Nations. (http://faostat.fao.org).

FAO (2018) Statistical Yearbook of the Food And Agricultural Organization for the United Nations. (http://faostat.fao.org).

Furlani PR, Zanetti M, Bataglia OC (2009) Citrus Nursery Production In Soilless Culture. Acta Hort. (ISHS) 843: 255-260.

Güneş A, Turan M, Şahin F, Haliloğlu K (2009) Organik tarımda biyogübrelerin kullanımı. http://docplayer.biz.tr/20773345Organik-tarimda-biyogubrelerin-kullanimi-adem-gunes-1-metinturan-1-fikrettin-sahin-2-kamil-haliloglu-3.html. Erişim 27 Şubat 2017.

Hetrick BAD, Wilson GWT (1989) Suppression of Mycorrhizal Fungus Spore Germination in Non-Sterile Soil: Relationship to Mycorrhizal Growth Response in Big Bluestem. Mycologia 81(3): 382-390.

Kahlke CJ, Watson JW, Gracia NS, Skaria M, John DG (2005) The Texas citrus budwood certification program. International Organization of Citrus Virologists Conference Proceedings (19572010), 16(16). Retrieved from https://escholarship.org/uc/item/98d6c077.

Menge JA, Johnson ELV, Platt RG (1978) Mycorrhizal Dependency of Several Citrus Cultivars Under Three Nutrient Regimes. New Phytol. 81: 553-559.
Mıșraklı D (2018) Topraksız Koşullarda Yetiștirilen Meyer Limonunda Farklı Besleme Kombinasyonlarının Fidan Kalitesi Üzerine Etkileri. Yüksek Lisans Tezi, Akdeniz Üniversitesi Fen Bilimleri Enstitüsü, Antalya.

Nunes MD, Soares ACF, Soares WD, Ledo CAD (2006) Natural Mycorrhizal Colonization of Citrus Rootstocks Under Field Conditions. Pesquisa Agropecuarı Brasileıra 41(3): 525-528.

Ortaş I, Ortakçı D, Kaya Z (2002a) Various Mycorrhizal Fungi Propagated on Different Hosts Have Different Effect on Citrus Growth and Nutrient Uptake. Communications in Soil Science and Plant Analysis 33(1\&2): 259-272.

Ortaş I, Ortakçı D, Kaya Z, Çınar A, Önelge N (2002b) Mycorrhizal Dependency of Sour Orange (Citrus Aurantium L.) In Term of Phosphorus and Zinc Nutrition by Different Levels of Phosphorus and Zinc Application. Journal of Plant Nutrition 25(6): 1263-1279.

Phillips JM, Hayman DS (1970) Improved Procedures for Clearing Roots and Staining parasitic and Vesicular-Arbuscular Mycorrhizal Fungi for Rapid Assessment of Infection. Transactions of the British Mycological Society 55: 157-160.

Pozo MJ, Azcon-Aguilar C (2007) Unravelling mycorrhiza-induced resistance. Current Opinion in Plant Biology 10: 393-398, pp. 453469.

Saygılı H, Şahin F, Aysan Y (2006) Fitobakteriyoloji. Meta Basım Matbaacılık Hizmetleri, İzmir, Türkiye, s. 530.

Siddiqui ZA (2006) Prospective biocontrol agents of plant pathogens. PGPR.

Singh B, Singh Y, Ladha JK, Bronson KF, Balasubramanian B, Singh J, Khind JS (2001) Chlorophyll Meter- and Leaf Color Chart-Based Nitrogen Management for Rice and Wheat in Northwestern India. Agron. J. 94: 821-829.

Schumann AA, Rogers M, Brlansky R, Grosser J, Gmitter F, Vashisth T (2015) Advanced Citrus Production Systems (ACPS). Field Day Handout. October 29, University of Florida, IFAS, Citrus Research and Education Center Lake Alfred, Florida.

Yılmaz E (2005) Topraksız Ortama Arbusküler Mikoriza Aşılamanın Patlıcan (Solanum Melongena L.) Yetiştiriciliği Üzerine Etkileri. Doktora Tezi, s. 204. 